\title{
CONCLUSIVENESS OF THE MERITS OF A TAX ASSESSMENT AND THE CONGRESSIONAL POLICY OF SUMMARY TAX COLLECTION*
}

CoNGREsS has given the Internal Revenue Service a formidable array of weapons for collecting federal taxes after assessment. But the taxpayer's right judicially to contest such collection is far more restricted. Several statutory provisions which preclude judicial interference with collection indicate a congressional intent to limit litigation of the taxpayer's liability before payment of the tax. The application of this restrictive policy of payment before adjudication has presented particular difficulty in two situations: a suit by the Government under section 7403 of the Internal Revenue Code to foreclose a tax lien, and a suit by a private party, in which the Government is joined under section 2410 of the Judicial Code, to foreclose a lien upon or to quiet title to property on which there is a tax lien. A recent decision of the Second Circuit ${ }^{1}$ holding that the merits of the Government's tax claim may be adjudicated in a section 7403 foreclosure suit seems inconsistent with the congressional policy of summary tax collection. In expressly renouncing the reasoning of a case ${ }^{2}$ decided shortly before this decision, the court has also cast doubt upon whether the merits are closed in a section 2410 proceeding.

A federal tax lien may not be established on a taxpayer's property until the Internal Revenue Service assesses an amount due from the taxpayer. ${ }^{3}$ Several steps precede the assessment of a tax deficiency. When a deficiency is contested by the taxpayer, the Government initially attempts to settle the dispute through informal conferences. ${ }^{4}$ If this method fails, one of two procedures is followed, depending on the kind of tax involved. ${ }^{5}$ Where the dispute involves any tax other

*United States v. O'Connor, 291 F.2d 520 (2d Cir. 1961).

1. United States v. O'Connor, 291 F.2d 520 (2d Cir. 1961).

2. Pipola v. Chicco, 274 F.2d 909 (2d Cir. 1960), overruled in part, United States v. O'Connor, supra note 1.

3. INT. Rev. CODE of 1954 [hereinafter cited as I.R.C.] \& 6321 provides:

If any person liable to pay any tax neglects or refuses to pay the same after demand, the amount ... shall be a lien in favor of the United States upon all property . . . belonging to such person.

The lien actually arises after demand, but its priority relates back to the time of assessment. I.R.C. $\$ 6322$.

The Code also provides for special liens in the cases of the estate tax, I.R.C. $\$ 6324$ (a), the gift tax, I.R.C. $\$ 6324$ (b), and the distilled spirits tax, I.R.C. \$ 5004. Although these special liens do not require an assessment, they co-exist with the I.R.C. $\S 6321$ lien once assessment and demand for payment have been made.

4. Rev. Proc. 57-26, 1957-2 CuM. Bull. 1093; Treas. Reg. §§ 601.103 (1959), 601.105 (1960), 601.106 (1959), 601.501 (1955), 601.502 (1959).

5. For certain types of stamp taxes, other procedures may be used. For a list of the various types of taxes, see Treas. Reg. $§ 601.102$ (1954). 
than an income, estate, or gift tax, the assessment is immediately made. ${ }^{6}$ In the case of an income, estate, or gift tax, however, a ninety-day deficiency letter is sent to the taxpayer. ${ }^{7} \mathrm{He}$ then has an opportunity to litigate the merits of the Government's claim in the Tax Court before payment, if he files a petition within ninety days. ${ }^{8}$ Assessment of the tax is stayed during this period and, if recourse is had to the Tax Court, until a final decision on the merits. ${ }^{0}$ An assessment is then made of the amount of the deficiency, if any, as determined by the Tax Court. ${ }^{10}$ When the taxpayer does not use the Tax Court procedure, Congress has clearly provided only one other method for litigating the merits of the tax claim. After payment of the whole ${ }^{11}$ assessment, the taxpayer may, by statute, sue the United States for a refund ${ }^{12}$ in either the district court ${ }^{13}$ or the Court of Claims. ${ }^{14}$

After assessment of the deficiency, there are two procedures generally used for collecting the tax. If the taxpayer fails to pay the amount claimed to be

6. P-H Excise TAXes ff 192,754 (1962) ; Plumb, Federal Tax Collection and Licn Problems, 13 TAx L. Rev. 247, 248 (1958). The assessment is made pursuant to I.R.C. $\$$ 6201.

7. I.R.C. $\$ 6212$; Treas. Reg. $\$ 601.103$ (1959).

8. I.R.C. $\$ 6213$. One hundred and fifty days are allowed if the taxpayer is outside of the United States.

9. But see note 31 infra and accompanying text.

10. I.R.C. $\$ 6215$. I.R.C. $\$ 6303$ provides that the taxpayer is to be notified within 60 days of the making of the assessment and demand is to be made upon him for payment. Treas. Reg. $\$ 301.6303-1$ (1954) states, however, that notice given after 60 days is still valid.

11. See Flora v. United States, 357 U.S. 63 (1958), aff'd on rehearing, 362 U.S. 145 (1960). In Freeman v. United States, 265 F.2d 66 (9th Cir. 1959), however, the taxpayer was allowed to maintain a refund suit upon partial payment of the assessment, because the Government had counterclaimed for the full amount of the deficiency. But see Anderson v. Myers, 170 F. Supp. 417 (N.D.N.Y. 1958).

In the second Flora opinion, the Court suggests that since some excise taxes may be divisible into separate taxes on each transaction, the "full-payment rule would probably require no more than payment of a small amount." 362 U.S. at 175 n.38. For cases which allow such division of the assessment, see Steele v. United States, 280 F.2d 89 (8th Cir. 1960) (withholding taxes and penalties); Christie v. United States, 179 F. Supp. 709 (D. Ore. 1959) (cabaret tax) ; Jones v. Fox, 162 F. Supp. 449 (D. Md. 1957) (cabaret tax).

12. I.R.C. $\$ \S 6511,6532,7422$.

13. 28 U.S.C. $\$ 1346$ (a) (1958).

14. 28 U.S.C. $\$ 1491$ (1958).

Another possibility is to sue the collector personally in the district court. Elliott v. Swartwout, 35 U.S. (10 Pet.) 137 (1836). The subsequent history of this type of refund suit is traced in Plumb, Tax Refund Suits Against Collectors of Internal Revenuc, $60 \mathrm{Harv}$. L. Rev. 685 (1947). For purposes of res judicata in such suits, the United States is deemed a party. I.R.C. $\$ 7422(\mathrm{c})$.

Considerations such as the taxpayer's cash position, interest on overpayments and underpayments, adherence to rules of evidence, the right to jury trial, precedents in the various circuits, and attitudes of different judges are considered in determining when and where to litigate. See Beaman, When Not To Go To The Tax Contr: Advantages and Procedures in Going to the District Court, 7 J. TAxation 356 (1957) ; Dockery, Refund Suits in District Courts, 31 Taxes 523 (1953); Walston, The Use of Juries in Federal Civil Income Tax Cases, 39 TAXEs 144 (1961). 
due, after assessment and demand, a lien relating back to the time of the assessment is created upon all his property. ${ }^{15}$ The Government may then proceed directly against the taxpayer's property to secure payment of the tax, either through a section 7403 judicial foreclosure proceeding or, under its distraint power, by administrative seizure and sale. ${ }^{16}$ Section 7403 of the Internal Revenue Code provides:

[T] he Attorney General . . . may direct a civil action to be filed in a district court . . . to enforce the lien of the United States . . . .

The court shall ... proceed to adjudicate all matters involved therein and finally determine the merits of all claims to and liens upon the property, and, in all cases where a claim or interest of the United States therein is established, may decree a sale of such property ... and a distribution of the proceeds of such sale according to the findings of the court....

Where the extent of the taxpayer's interest in particular property is clear, distraint is the quickest, the most effective, and therefore the principal method of collection. ${ }^{17}$ Where there are conflicting claims of ownership, however, a distraint sale is unsatisfactory because of the threat of possible litigation 18 and because a low price ${ }^{19}$ will result from the uncertainty of title. In such cases the Government is likely to resort to a judicial foreclosure proceeding in which the interests of all parties may be adjudicated. ${ }^{20}$ The Government may also sue the taxpayer for a personal judgment. Because this latter action, however,

15. See note 3 supra.

16. I.R.C. $\$ 6331$ allows the Secretary or his delegate to levy upon the property of the delinquent taxpayer 10 days after notice and demand for payment of the tax. IRC $\S 6335$ provides for a sale after notice to the taxpayer of the seizure.

17. For the fiscal years 1952,1953 , and 1954 there were respectively $1,389,297,1,700,406$, and $1,529,287$ distraint warrants collected. During this same period there were 114,259 , and 189 court proceedings instituted by the United States to collect taxes or to recover erroneous refunds (omitting those relating to alcohol, tobacco, and firearms taxes). 1952 INT. REv. Serv. Ann. Rep. 20,283; 1953 Int. Rev. Serv. Anv. Rep. 21,153; 1954 Int. Rev. Serv. Anv. REP. 16,100. Since 1955 the IRS has reported its statistics by delinquent accounts rather than by distraint warrants.

18. This is because the distraint sale will pass only the interest of the taxpayer in the property. I.R.C. $\$ 6339$. See, McHale, supra note 18, at 612; Plumb, Federal Tax Collection and Licn Problems, 13 TAx L. Rev. 459, 540 (1958). In United States v. Stock Yards Bank, 231 F.2d 628, 631 (6th Cir. 1956), it was said :

[D]istraint is no doubt a useful tool in the effective enforcement of the Internal Revenue laws. But it is a blunt instrument, ill-adapted to carve out property interests where their nature and extent are unclear.

A judicial foreclosure will permit adjudication of all conflicting claims to the property and thus conveyance of certain title. A further advantage of judicial foreclosure is the avoidance of the one year redemption provision for real property sold through a distraint sale. I.R.C. § 6337(b).

19. Letter from Richard M. Roberts, Chief, General Litigation Section of the Tax Division, United States Department of Justice, to the Yale Law Journal, Nov. 22, 1961, on file in Yale Law Library; McHale, Tax Liens; So. Cad. 11tre Tax Inst. 607, 612 (1959).

20. See note 18 supra. 
allows the taxpayer to litigate the merits, ${ }^{21}$ and because the collection procedures better insure payment of the tax, a suit for a personal judgment is used primarily where distraint or foreclosure is not feasible in order to toll the six year statute of limitations on collection. ${ }^{22}$

After creation of the Government's tax lien, but before collection, section 2410 of the Judicial Code permits the taxpayer ${ }^{23}$ or a third party ${ }^{24}$ with an interest in property affected by a federal tax lien to join the United States in a suit to foreclose a lien upon or quiet title to property subject to the tax lien. This section provides:

[T] he United States may be named a party in any civil action or suit in any district court, or in any state court having jurisdiction of the subject matter, to quiet title to or for the foreclosure of a mortgage or other lien upon real or personal property on which the United States has or claims a mortgage or other lien. ${ }^{25}$

The statutory collection scheme reflects a congressional desire to insure rapid tax collection with a minimum of interference from the taxpayer. This is seen, for example, in the distraint provision allowing the Government to seize and sell the taxpayer's property without a prior judgment ${ }^{26}$ ordinarily such a judgment is a prerequisite to any levy upon a debtor's property. ${ }^{27}$ The same congressional intent is also found in the provision of the Internal Revenue Code which prohibits the courts from enjoining the assessment or

21. See note 36 infra.

22. Hector v. United States, 255 F.2d 84 (5th Cir. 1958) (suit several weeks prior to the expiration of the statute of limitations); United States v. Szerlip, 169 F. Supp. 529 (E.D.N.Y. 1959) (suit to reduce claim to judgment eleven days before collection would be barred; dismissed in part because timely assessment was not made). See Bowen, Tax Liens: Their Extent and Priority, N.Y.U. 13TH INST. on FEd. TAX 1093, 1096 (1955).

23. Guttman v. United States, 196 F. Supp. 384 (E.D.N.Y. 1961) ; Coson v. United States, 169 F. Supp. 671 (S.D. Cal. 1958), modified on other issue, 286 F.2d 453 (9th Cir. 1961) ; Sanders v. Andrews, 121 F. Supp. 584 (W.D. Okla. 1954), rev'd on other grounds, 225 F.2d 629 (10th Cir. 1955).

24. E.g., Tower Prod. Co. v. United States, 61 F. Supp. 411 (W.D. Okla. 1945); United States v. Weissman, 135 So. $2 d 235$ (Fla. Dist. Ct. App. 1961).

25. 28 U.S.C. $\$ 2410$ (1958).

26. I.R.C. $\S 6331$ provides that the Secretary or his delegate may levy upon the property of the taxpayer ten days after notice and demand except upon property exempted by I.R.C. $\$ 6334$.

In an action by the United States to enjoin a lessee from making rent payments to stockholders of the taxpayer, the court stated:

[T] he tax is not like an ordinary claim; the [Government] need not wait for judgment in order to levy execution; it can distrain ten days after notice and demand.... And if it can distrain and sell without any judgment, not only the lessor's chattels, but this very chose in action, the assessment is itself the equivalent of a judgment for purposes of collection.

United States v. Morris \& E. R.R., 135 F.2d 711, 713 (2d Cir.), cert. denied, 320 U.S. 754 (1943).

27. 33 C.J.S., Executions $\$ 5$ (1942). 
collection of taxes. ${ }^{28}$ A further indication of this policy is the 1935 amendment to the Declaratory Judgment Act which precludes its application to questions of federal taxation. ${ }^{29}$ The Tax Court procedure is admittedly an exception to the policy of summary tax collection. ${ }^{30}$ But the taxpayer is not assured an opportunity of litigating the merits before payment even under this procedure; where delay may endanger the collection of the tax, the jeopardy provisions of the Code authorize seizure of the taxpayer's property before adjudication in the Tax Court. ${ }^{31}$

Notwithstanding the policy implicit in the statutory collection scheme, the Second Circuit, in United States $v . O^{\prime}$ Connor, ${ }^{32}$ held that a taxpayer may challenge the merits of the assessment in a section 7403 foreclosure suit. In Pipola v. Chicco, ${ }^{33}$ a case decided shortly before $O^{\prime}$ Connor, the same court, relying on a Supreme Court dictum, ${ }^{34}$ held that a tax assessment had the force and conclusive effect of a judgment. Although $P$ ipola was a section 2410 suit, the court reasoned that since the assessment has the force of a judgment, its merits could not be contested in a section 7403 suit, and therefore should not be open in an action brought under section 2410. It is this reasoning that was expressly overruled in $O^{\prime}$ Connor..$^{35}$

Three grounds are given for the court's present position. First, the court relies on two early Supreme Court decisions holding that when the Government brings an action for a personal judgment against the taxpayer, the merits of the assess-

28. I.R.C. $\$ 7421$ (a). The injunction prohibition first appeared in 1867. 14 Stat. 475 , Rev. Stat. § 3224 (1875). See Note, 49 Harv. L. Rev. 109 (1935).

The section allows an injunction, however, if collection is made without sending the taxpayer his ninety-day letter (see I.R.C. $\$ 6212(a)$ ) or while the Tax Court is hearing the case (see I.R.C. \& $6213(\mathrm{a})$ ).

29. 49 Stat. 1027, 49 U.S.C. $\$ 2201$ (1958). The policy reflected in these provisions has been justified on several grounds: the Government's immediate need of reventue, insurance of the smooth and orderly functioning of the statutory collection procedure, and protection against delaying tactics by recalcitrant taxpayers. Bull v. United States, 295 U.S. 247, 259 (1935); Cheatham v. United States, 92 U.S. 85, 89 (1875); State Railroad Tax Cases, 92 U.S. 575, 613 (1875) ; Wilson v. Wilson, 141 F.2d 599, 600 (4th Cir. 1944).

30. Congress apparently felt that the possibility of hardship resulting from there being no means of contesting the deficiency before payment outweighed the burden of interference which would result from allowing this limited opportunity to challenge the tax. See H.R. Rep. No. 179, 68th Cong., 1st Sess. 7 (1924) ; S. Rep. No. 398, pt. 1, 68th Cong., 1st Sess. 8 (1924). See also Flora v. United States, 362 U.S. 145, 159 (1960).

31. I.R.C. $\$ 6861$. The sale of the property seized pursuant to such assessment is, however, ordinarily stayed. I.R.C. $\S 6863(\mathrm{~b})$ (3). The seizure may be stayed by the filing of a bond. I.R.C. $\$ 6863$ (a).

32. 291 F.2d 520 (2d Cir. 1961).

33. 274 F.2d 909 (2d Cir. 1960), overriled in part, United States v. O'Connor, 291 F.2d 520 (2d Cir. 1961). The I.R.C. citations in the Pipola decision are to the 1939 Code. The present I.R.C. § 7403 differs only slightly in wording from I.R.C. $\$ 3678$ of the 1939 Code. Citations in this Note will be to I.R.C. $\$ 7403$ only.

34. Bull v. United States, 295 U.S. 247, 260 (1935).

35. 291 F.2d at 526 . 
ment may be contested..$^{36}$ These decisions are viewed as more applicable to the section 7403 foreclosure suit than the Court's dictum that an assessment has the force of a judgment, because the latter statement was made in the context of the distraint power, and not in the context of the Government's rights once it has voluntarily instituted a judicial action. Looking at the statutory language, the court notes that section 7424, the provision of the Internal Revenue Code which deals with quiet title and foreclosure suits ${ }^{37}$ brought by private parties, expressly provides that "the assessment . . . shall be conclusively presumed valid"; the significance of the absence of such a provision in section 7403 of the Code is increased in the court's view by the fact that the two provisions were originally contained in the same section of the Revised Statutes. Finally, the court reconsiders the legislative history of section 7403 which it found inconclusive in Pipola $v$. Chicco. ${ }^{38}$ It was pointed out in Pipola that when, in 1954, the House Committee added a provision to section 7403 making the merits of the assessment conclusive, ${ }^{39}$ the Senate Committee eliminated the amendment. This fact was deemed insignificant by the court in Pipola, since the House labeled the addition an "express provision" and the Senate said that its deletion was "not designed to change the . . . existing law . . .."40 In the court's later view in O'Connor, however, the deletion takes on a new meaning when read in conjunction with a statement at the Senate Hearings by the Association of the Bar of the City of New York. The Association stated that since the taxpayer may contest the merits in the Government's suit for a personal judgment, "it seems illogical to deny such right to the taxpayer in a suit to enforce a tax lien." 41

The reasons given for the reversal of the Pipola rationale in O'Connor are not compelling. While it is true that the merits may be challenged in a personal judgment action, this proceeding is distinguishable from a section 7403 foreclosure suit. The purpose of a suit to reduce the assessment to a personal

36. United States v. Rindskopf, 105 U.S. 418 (1881) ; Clinkenbeard v. United States, 88 U.S. (21 Wall.) 65 (1874). The court in O'Connor noted that these two cases were not brought to its attention in Pipola. Several lower court decisions have indicated that the merits of the assessment may be challenged in a suit by the Government for a personal judgment. United States v. Acri, 109 F. Supp. 943 (N.D. Ohio 1952), aff'd per curiam, 209 F.2d 258 (6th Cir. 1953), rev'd on other grounds, 348 U.S. 211 (1955); United States v. Szerlip, 169 F. Supp. 529 (E.D.N.Y. 1959) ; Bowers v. American Sur. Co., 30 F.2d 244 (2d Cir.), cert. denied, 279 U.S. 865 (1929). But see United States v. Hauser, 25 F. Supp. 689 (S.D. Cal. 1938).

37. I.R.C. $\$ 7424$ provides that a prior interest holder may request the Internal Revenue Service to institute an action to foreclose the tax lien. If the IRS does not foreclose within six months, the prior interest holder may file a petition with the district court to determine all claims and liens to the property. There has been some conflict of authority as to whether a sale of the property is required. See Annot., 105 A.L.R. 1260 (1936).

38. $274 \mathrm{~F} .2 \mathrm{~d}$ at 912.

39. H.R. Rep. No. 1337, 83d Cong., 2d Sess. A431 (1954).

40. S. Rer. No. 1622, 83d Cong., 2d Sess. 610 (1954).

41. Hearings on H.R. 8300 Before the Senate Committee on Finance, 83d Cong., 2d Sess., pt. 1, at 612 (1954). 
judgment is to toll the statute of limitations; 42 if adjudication of the Government's claim is not allowed in this action, the entire proceeding of obtaining a judgment against the taxpayer would be a meaningless formality, for there would be no issue to litigate. And, since the tax lien reduced to a judgment is enforceable indefinitely, ${ }^{43}$ there would be no limitation on the time during which the taxpayer or the Government could litigate the merits of the underlying tax liability. On the other hand, a section 7403 action, like its counterpart distraint, seems to be primarily a method of collecting an assessment.44 Preclusion of the merits in a section 7403 suit still allows litigation of the primary issue of conflicting claims to the taxpayer's property. This construction of section 7403, moreover, does not impair the Code's six year statute of limitations on collection of an assessment ${ }^{45}$ and the two year limitation on a refund suit. ${ }^{46}$ The merits would thus have to be litigated within this eight year period. The legislative history of section 7403, which was relied upon by the court in $O^{\prime}$ Connor, seems inconclusive, for the statement of the Bar Association is merely a comment as to what it believes the law should be, and does not define "existing law." Existing law prior to the 1954 revision of section 7403 was, in fact, almost nonexistent. ${ }^{47}$ Moreover, the statutory language of section 7403, even when read in the light of the express statement giving the assessment conclusive validity in section 7424 , does not seem decisive of the issue.

The holding in $O^{\prime}$ Connor, $^{48}$ furthermore, seems contrary to the policy of summary tax collection. The only court-made exceptions to the general rule of payment before litigation, other than the section 7403 foreclosure suit, are

42. See note 22 supra and accompanying text.

43. United States v. Ettelson, 159 F.2d 193 (7th Cir. 1947); Investment \& Sec. Co. v. United States, 140 F.2d 894 (9th Cir. 1944) ; United States v. Walley, 160 F. Supp. 67 (S.D. Cal.), rev'd on other grounds, 259 F.2d 579 (9th Cir. 1958). Although a judgment lien is subject to the state statute of limitations, 28 U.S.C. $\$ 1962$ (1958), the tax lien after judgment will last indefinitely. Plumb, supra note 6 , at 250-51. However, some legal writers have expressed the view that the tax claim after judgment will be subject to the state statute of limitations on judgments. Bowen, supra note 22, at 1103; Wahl, The Assessment and Collection of Federal Incone Taxes, 3 MIAsr L.Q. 209, 223 (1949). Even under this view the merits of the tax claim might not be decided until after eight years from the time of the assessment. See notes 45 and 46 infra and accompanying text.

44. See note 18 supra.

45. I.R.C. $\$ 6502$. This period can be extended by an agreement between the taxpayer and the IRS.

46. I.R.C. $\$ 6511(\mathrm{a})$.

47. But see United States v. Rindskopf, 27 Fed. Cas. 816 (No. 16,166) (C.C.E.D. Wis. 1879). United States v. Feazel, 49 F. Supp. 679 (W.D. La. 1943) indicated that a contest on the merits is allowable in an I.R.C. $\$$ 7403 suit. Since 1954 two courts have permitted the taxpayer to raise the merits in an I.R.C. [\$ 7403] suit: United States v. Hoper, 242 F.2d 468 (7th Cir. 1957) ; United States v. Ridley, 127 F. Supp. 3 (N.D. Ga. 1954). See Graham v. United States, 243 F.2d 919 (9th Cir. 1957).

48. The IRS itself requested a reconsideration of the Pipola rationale in $O^{\prime}$ Connor, and argued that the merits should be open in an I.R.C. \$ 7403 action. 291 F.2d at 526. The Government's reasons for taking this view in $O^{\prime}$ Comor are not clear. Whatever its reasons, 
when the taxpayer can show extreme hardship resulting from seizure of his property ${ }^{49}$ and when the Government sues the taxpayer for a personal judgment. ${ }^{50}$ Allowing litigation on the merits of the assessment under section 7403 will undoubtedly increase the time taken by the suit. Arguably, once the parties are before the court, consideration of the time and expense of a subsequent refund suit-in respect to both the parties and the court-may justify this delay in collection. Moreover, in a section 7403 suit, the Government has itself voluntarily chosen to bring a court action rather than use the more summary distraint procedure. But the Government brings a section 7403 foreclosure suit principally because title to the property subject to a federal tax lien is uncertain, which makes distraint an inappropriate proceeding, ${ }^{51}$ and not because of any reasons suggesting a congressional desire for less summary collection of taxes. In fact, the purpose of giving the tax collector a judicial foreclosure proceeding in addition to the distraint power apparently is to provide for the collection of the assessment where the taxpayer's title to property must be litigated before collection. This purpose does not indicate that a foreclosure action is to be any less summary than distraint. Furthermore, where the taxpayer could have availed himself of the Tax Court, it seems unfair to allow him to contest the merits before payment, for this "second chance" will be open only to those few taxpayers who refuse to pay voluntarily and whose assessment the Government decides to collect through judicial foreclosure rather than through distraint. Furthermore, to the extent that uncertainty of title is within the control of the delinquent taxpayer, the efficacy of the distraint power may be frustrated by the taxpayer.

There are additional reasons supporting the conclusion that the taxpayer should not be allowed to contest the merits in a suit in which the United States is joined under section 2410 of the Judicial Code. The Second Circuit's reversal of opinion as to allowable defenses in a section 7403 suit undermines

the fact that the Government desired to litigate the merits in an I.R.C. $\$ 7403$ suit is not determinative of the statutory question.

The $O^{\prime} C o m n o r$ decision leaves a number of questions unanswered: Will an I.R.C. $§ 7403$ suit settle the validity of the assessement to its full extent or only to the extent of the value of the property involved in the suit? What if the assessment is based on many complex issues or concerns liability for several years, and only a small parcel of property is involved in the I.R.C. \$ 7403 litigation? If the taxpayer does not appear to defend, can junior lienors litigate the validity of the assessment?

49. I.R.C. $\$ 7421$ (a) provides, with the exceptions noted in note 28 supra, that "no suit for the purpose or restraining the assessment or collection of any tax shall be maintained in any court." Despite the seemingly absolute language of the injunction provision, the courts have allowed suits for injunctions in special and extraordinary circumstances. This exception, however, has been limited to situations in which the court finds that the taxpayer's livelihood will be virtually destroyed if he is forced to pay an erroneous tax. See Miller v. Standard Nut Margarine Co., 284 U.S. 498 (1932); Enochs v. Williams Packing \& Nav. Co., 291 F.2d 402 (5th Cir.), cert. granted, 368 U.S. 937 (1961) ; Mensik v. Long, 261 F.2d 45 (7th Cir. 1958).

50. See note 36 supra.

51. See note 18 supra and accompanying text. 
its earlier decision holding that the assessment is conclusive in a section 2410 action ${ }^{52}$ brought by a third party ${ }^{53}$ to foreclose a lien upon or quiet title to property on which there is a federal tax lien. ${ }^{54}$ The court in O'Connor expressly refuses to decide whether its rejection of the Pipola rationale overturns the entire Pipola decision. ${ }^{.5}$

The arguments accepted by the court in $O^{\prime}$ Connor, based upon the absence of specific statutory language in section 7403 prohibiting examination of the merits and the presence of such an express provision in section 7424 of the Internal Revenue Code, are equally applicable to section 2410 . There is, however, more substantial legislative support for finding that the validity of the assessment may be questioned in a section 2410 suit. ${ }^{56}$ Section 2410 , as originally proposed by the House Judiciary Committee, was available only to third parties with liens superior to that of the Government. ${ }^{57}$ In conference the Senate Judiciary Committee prevailed in its view that the statute should be available to junior as well as senior lienors. 58 The Conference Committee report stated in explanation of the change that "Cases may often arise where a junior lien holder needs to be informed as to the validity, amount, etc., of a prior lien ....". Unless Congress intended some other issues to be open in a

52. Pipola v. Chicco, 274 F.2d 909 (2d Cir. 1960), overruled in part, United States v. O'Connor, 291 F.2d 520 (2d Cir. 1961).

53. Pipola was an action by a third party purchaser to remove a tax lien, which had been overlooked in the title search. In O'Connor the court noted the Government's contention that the Pipola decision was nevertheless correct because of "asserted differences" between the taxpayer and third parties. This distinction between the taxpayer and third parties would not protect the payment-before-litigation policy if the taxpayer sued under 28 U.S.C. $\S 2410$. See Johnson v. Granquist, 191 F. Supp. 591 (D. Ore. 1961); note 23 supra.

54. Under United States v. Brosnan, 363 U.S. 237 (1960), junior federal tax liens may be removed in a state court, without the joinder of the Government if local law so provides. The Brostan case has no application to prior Government liens. United States v. Roessling, 280 F.2d 933 (5th Cir. 1960); United States v. Mojac Constr. Corp., 190 F. Supp. 622 (E.D.N.Y. 1960).

55. 291 F.2d at 526.

56. It is clear that 28 U.S.C. $\$ 2410$ was intended to apply to tax cases. This is indicated by the statutory language itself; subsection (d) dealing with administration release of liens specifically treats the case of a tax lien. Moreover, the House Judiciary Committee report on the bill contains a statement that the proposed bill is important because "The number of liens filed under the revenue laws has been steadily growing." H.R. REP. No. 95, 71st Cong., 2d Sess. 2 (1929). The provision has been construed as applicable to tax liens by both the courts and the IRS. United States v. Brosnan, 363 U.S. 237 (1960) ; Miners Saving Bank v. United States, 110 F. Supp. 563 (M.D. Pa. 1953) ; G.C.M. 9453, X-1 CuM. BuzL. 526 (1931).

57. H.R. Rer. No. 2722, 71st Cong., 3d Sess. 3 (1931).

58. The Senate Committee Report stated:

The Government ought not to desire to occupy a dog-in-the-manger position with respect to its liens, neither taking steps to enforce them nor permitting others interested to test their validity or priority.

S. ReP. No. 351, 71st Cong., $2 \mathrm{~d}$ Sess. 2 (1930).

59. H.R. REP. No. 2722, 71st Cong., 3d Sess. 3 (1931). It may be argued that this statement and the statement in S. REP. No. 351, 71st Cong., 2d Sess. 2 (1930) merely mean the 
section 2410 suit, this change would make no sense as to junior lienors. If only priority ${ }^{60}$ could be tested in a quiet title or foreclosure action, a junior lienholder, by definition, could not successfully litigate this issue.

But prohibiting a dispute on the merits of the underlying tax liability does not render section 2410 totally without a function in tax lien cases. In foreclosure suits brought by junior lienors, such parties may still contest the procedural validity of the tax lien, on the ground that proper demand was not made on the taxpayer. ${ }^{.1}$ Moreover, since the extension of section 2410 to

validity of the lien, rather than the validity of the underlying assessment. See Commercial Credit Corp. v. Schwartz, 126 F. Supp. 728 (E.D. Ark. 1954). On the other hand, the term "amount" might be read as referring to the amount of the tax owed which could be determined only by consideration of the assessment itself, although it is likely that the drafters of the Report did not consider this implication of the word when they used it in the series "validity, amount, etc."

As passed, 46 Stat. 1528, what is now 28 U.S.C. $\$ 2410$, read :

[T] he consent of the United States . . is hereby given . . f for the foreclosure of a mortgage or other lien upon real estate, for the purpose of securing an adjudication touching any mortgage or other lien the United States may have or claim on the premises involved.

This purpose clause, mentioning liens, was apparently eliminated when Title 28 was codified in 1947. See H.R. Rep. No. 308, 80th Cong., 1st Sess. A188 (1947).

60. There is no specific statutory provision as to the relative priority of tax liens in the case of a solvent taxpayer. Under federal case law, the lien perfected "first in time is [ordinarily] first in right.' " United States v. New Britain, 347 U.S. 81, 85 (1954). Where the taxpayer is insolvent, priority is governed by either REV. STAT. $\$ 3466$ (1875), 31 U.S.C. $\S 191$ (1958), or the Bankruptcy Act, § 64, 30 Stat. 563, as amended, 11 U.S.C. § 104 (Supp. II 1961). Situations of insolvency or bankruptcy are beyond the scope of this Note.

61. In United States v. Coson, 286 F.2d 453 (9th Cir. 1961), the tax lien was removed from the taxpayer's property because of failure to make proper demand upon the taxpayer. The issue of demand has also been raised in suits to determine the distribution of or claims to assets of the taxpayer. See, e.g., United States v. Pavenick, 197 F. Supp. 257 (D. N.J. 1961) (Government claim for a lien would be disallowed without proof of demand); Sherman B. Ruth, Inc. v. O.S.V. The Marie and Winifred, 150 F. Supp. 630 , modified on rehearing, 155 F. Supp. 37 (D. Mass. 1957) (Government lien denied priority in absence of evidence that demand was made on the taxpayer; however, on rehearing, the court found sufficient demand to comply with IRC $\$ 6321$ ); Cattani v. Korsan, 29 N.J. Super. 581, 103 A.2d 51 (Ch. 1954), appeal dismissed on other grounds, 32 N.J. Super. 210, 108 A.2d 110 (App. Div. 1954) (private competing lienor allowed to raise issue whether or not demand was made on the taxpayer); In re Holdsworth, 113 F. Supp. 878 (D.N.J. 1953) (Government lien would be held invalid if the Government could not prove demand). But sec, Macatee, Inc. v. United States, 214 F.2d 717, 719 (5th Cir. 1954) stating that the purpose of requiring notice and demand is to protect the taxpayer and has little or no relation to determining priority of liens between the United States and other lienors.

As a matter of policy, it is doubtful that demand should be a prequisite to a valid lien. It is anomalous that a taxpayer who has received at least one deficiency letter and who has been given the opportunity to confer with the Service should be able to invalidate a lien for failure to make demand. And it is still more strange to allow a third party lienor to complain not of a failure to notify him, but of a failure to make demand upon the taxpayer. What is now the I.R.C. § 6321 lien first appeared in 1866, 14 Stat. 107, REv. STAT. \& 3186 (1875), and the original wording of the demand requirement has been substantially retained. 
quiet title suits in $1942,{ }^{62}$ interested third parties may litigate whether the tax lien has been erroneously placed on property not belonging to the taxpayer. ${ }^{63}$ Adjudication of both these issues is justified on the ground that it does not interfere with summary collection of the tax..$^{\text {of }}$ As long as the underlying tax liability is not adjudicated, the Government is still free to levy upon property of the taxpayer. ${ }^{65}$

In spite of the unqualified statutory language and general statements in the legislative history, there are strong reasons for concluding that the merits of the tax assessment should not be contestable in a suit under section 2410 . To allow adjudication would seriously impair the Government's power to use distraint as well as foreclosure proceedings for summary collection of the assessment. Since section 2410 suits are instituted by private parties, and not by the Government, the taxpayer or third party could, at any time prior to distraint, bring the property into the control of a court by means of an action under section $2410,{ }^{60}$ presumably thereby precluding the use of distraint. ${ }^{07}$

62. In the Committee Reports on the 1942 amendment to the section, no mention is made of tax liens. The report suggests that the Committee was primarily concerned with extending 28 U.S.C. $\$ 2410$ to personalty and with various liens created by certain farm agencies of the Government. The extention of 28 U.S.C. $\$ 2410$ to quiet title suits was suggested by Attorney General Jackson in a letter to the Committee. The letter stated :

It should be observed ... that under existing law there is no provision whereby the owner of real estate may clear his title to such real estate of the cloud of a Government mortgage or lien....

In many instances persons acting in good faith have purchased real estate without knowledge of the Government lien in the belief that the lien had been extinguished. In other instances, mortgagees have foreclosed on property and have failed to join the United States. It appears that justice and fair dealing would require that a method be provided to clear real-estate titles of questionable or valueless Government liens. H.R. REP. No. 1191, 77th Cong., 1st Sess. 2 (1941) ; S. REP. No. 1646, 77th Cong., 2d Sess. 2 (1942).

63. E.g., National Iron Bank v. Manning, 76 F. Supp. 841 (D.N.J. 1948) ; Tower Prod. Co. v. United States, 61 F. Supp. 411 (W.D. Okla. 1945). Moreover, 28 U.S.C. \$ 2410 (c) (1958) provides that the property can be sold to satisfy a lien inferior to the tax lien, although the tax lien will remain unaffected.

64. Rothensies v. Ullman, 110 F.2d 590 (3rd Cir. 1940).

65. Tomlinson v. Smith, 128 F.2d 808, 811 (7th Cir. 1942).

66. Smith v. United States, 254 F.2d 865 (6th Cir. 1958). See Heidritter v. Elizabeth Oil-Cloth Co., 112 U.S. 294 (1884). See generally, 1A Moore, Federal Practice If 0.214-17, 0.222-23 (2d ed. 1961).

67. See Treas. Reg. $\$ 301.6331-1$ (a) (3) (1955). Cf., United States v. Mercantile Trust Co., 62 F. Supp. 837 (D. Md. 1945), modifying Mercantile Trust Co. v. Hofferbert, 58 F. Supp. 701 (D. Md. 1944) ; United States v. Feazel, 49 F. Supp. 679 (W.D. La. 1943) ; United States v. Swink, 41 F. Supp. 98 (E.D. Va. 1941); Thomas v. Texas, 20 Am. Fed. Tax R. 1346 (N.D. Tex. 1937). In Smith v. United States, 254 F.2d 865 (6th Cir. 1958), the court reversed a lower court decree ordering foreclosure of a tax lien on the grounds that the property was brought under the control of a state court in a suit to quiet title in which the Government was joined pursuant to 28 U.S.C. \$2410. .

However, even though the state court has control of the res, an in personam decree establishing the federal claim may be secured in another court. Kline v. Burke Constr. Co., 
Such power by the taxpayer and third parties over whether or not the tax liability is adjudicated before payment would effectively undermine the policy prohibiting judicial interference with the collection of the tax, as provided by the anti-injunction provision ${ }^{68}$ and the amendment to the Declaratory Judgment Act. ${ }^{69}$ Adjudication of the underlying tax liability in a section 2410 suit seems, in fact, the equivalent of a declaratory judgment. ${ }^{70}$ Since section 2410 is in the Judicial Code and not the Internal Revenue Code, and since it applies to all foreclosure and quiet title suits involving property on which the United States has a lien or mortgage, it should not be presumed without clear evidence that in enacting section 2410 Congress intended to work so radical a change in the tax collection system. It is, indeed, likely that had the statute not been narrowly applied by the courts in tax cases, ${ }^{71}$ it would have

260 U.S. 226 (1923) ; Hart v. United States, 207 F.2d 813 (8th Cir. 1953), cert. denied, 347 U.S. 919 (1954); United States v. Acri, 109 F. Supp. 943 (N.D. Ohio 1952), aff'd per curiam, 209 F.2d 258 (6th Cir. 1953), rev'd on other grounds, 348 U.S. 211 (1955).

68. I.R.C. $\$ 7421$.

69. The Senate Finance Committee Report indicates that the Declaratory Judgment Act was amended to prohibit its application to federal tax cases because :

The application of the Declaratory Judgment Act to taxes would constitute a radical departure from the long-continued policy of Congress (as expressed in Rev. Stat. 3224 [I.R.C. \$ 7421-the anti-injunction provision] and other provisions) with respect to the determination, assessment, and collection of federal taxes. Your committee believes that the orderly collection of federal taxes should not be interfered with by a procedure designed to facilitate the settlement of private controversies . . . .

S. Rep. No. 1240, 74th Cong., 1st Sess. 11 (1935). Compare Wideman, Application of the Declaratory Judgment Act to Tax Suits, 13 TAXEs 539 (1935), with Borchard, DeclaraTORY JUDGMENTS 850 (2d ed. 1941).

70. In Flora v. United States, 362 U.S. 145, 164-65 (1960), Mr. Chief Justice Warren said in connection with the question of whether a refund suit could be maintained upon partial payment of the assessment :

It is clear enough that one "radical departure" which was averted by the amendment was the potential circumvention of the "pay first and litigate later" rule by way of suits for declaratory judgments in tax cases. Petitioner would have us give this Court's imprimatur to precisely the same type of "radical departure," since a suit for recovery of but a part of an assessment would determine the legality of the balance by operation of the principle of collateral estoppel. With respect to this unpaid portion, the taxpayer would be securing what is in effect-even though not technicallya declaratory judgment. The frustration of congressional intent which petitioner asks us to endorse could hardly be more glaring, for he has conceded that his argument leads logically to the conclusion that payment of even $\$ 1$ on a large assessment entitles the taxpayer to sue....

Under 28 U.S.C. $\$ 2410$ a similar "frustration of congressional intent" would result even without the payment of one dollar if the merits of the assessment were open.

71. See Pipola v. Chicco, 274 F.2d 909 (2d Cir. 1960), overruled in part, United States v. O'Connor, 291 F.2d 520 (2d Cir. 1961) ; Johnson v. Granquist, 191 F. Supp. 591 (D. Ore. 1961) ; Stanford Construction Corp. v. United States, 59-2 U.S. Tax Cas. $₫ 9580$ (S.D. Cal. 1958) ; Commercial Credit Corp. v. Schwartz, 126 F. Supp. 728 (E.D. Ark. 1954) ; Viviano v. United States, 105 F. Supp. 312 (E.D. Mich. 1952). It was stated by Mr. Justice Clark in United States v. Brosnan, 363 U.S. 237, 260 (1960) (dissent on another issue), that 
been promptly amended, as was the Declaratory Judgment Act soon after its application to tax cases. ${ }^{72}$ The application of section 2410 in tax cases should thus be limited by the provisions and policies of the summary collection system of the revenue laws.

the merits of the tax assessment are conclusive in a $\S 2410$ suit; no reason was given, however. But see, Macatee, Inc. v. United States, 214 F.2d 717 (5th Cir. 1954); United States v. Morrison, 247 F.2d 285, 290 (5th Cir. 1957) (dictum). Two commentators have concluded that the merits of the assessment are open in a $\$ 2410$ suit; Clark, Federal Tax Liens and Their Enforcement, 33 VA. L. REv. 13, 36 (1947); Sarner, Federal Tax Liens, N.Y.U. 19 TH INST. on Fed. TAX 1431, 1456 (1960).

72. See note 69 supra. 